\title{
Students' Reading Habit and Students' Writing Introduction in Research Seminar Proposal
}

\author{
Hernik Ferisia \\ Faculty of Education \\ UIN Sunan Ampel Surabaya
Mohammad Annas Miftakhuddin Faculty of Education
UIN Sunan Ampel Surabaya
annasmifta@gmail.com

\author{
Aula Bidayatul Hidayah \\ Faculty of Education \\ UIN Sunan Ampel Surabaya \\ aulabidayatulh@gmail.com \\ Nurul Huda \\ Faculty of Education \\ UIN Suan Ampel Surabaya \\ Nurullhuda0598@gmail.com
}

\begin{abstract}
Students must master a writing skill in making an introduction in the research proposal. Students also more read a book or e-book to get the information for making an introduction. Introduction is the firstpart written in a research proposal. The aim of this research is to find out the correlation between students' reading habit and their ability to write anintroduction in Research Seminar Proposal. Is there any correlation between a student's reading habit and writing skill introduction in the Research Seminar Proposal andHow far the correlation between students' reading habits and writing skill introduction in Research Seminar Proposal at the sixth ofEnglish Teacher Education Department of State Islamic University Sunan Ampel Surabaya. The research design used quantitative research. The data were collected through a questionnaire. The questionnaires were distributed to 33 students in Research Seminar Proposal A class. The findings revealed that theparticipants in this study have the same appointment.The students who have a good reading habit also have a good skill writing ability. The researchers hope this study helpsthe students to make good writing in introduction of Research Seminar Proposal.
\end{abstract}

Keywords: writing skill, reading habit

\section{INTRODUCTION}

The importance of writing skills in communication cannot be underestimated because through a writing students can transfer the information and knowledge they have to others. Besides, writing is also a way to express the ideas. According to Elshtain as quoted by Murcia, a text can be said as a communication action. Through a text can also occur interaction between readers and writers. (Boston: Thomson Learning Inc, 2001). This fact shows that in writing, writers and readers alike have an important role, while writing skills are considered as challenging for students and are considered as the most complicated activities compared to three other language skills in English. This is corroborated by Brown's opinion which stated that writing is a complex activity that requires a great deal of expertise to translate ideas into a piece of paper. Besides, to compose a good writing requires some coordination such as vocabulary, grammar, critical thinking skills, background knowledge, etc.

The research seminar proposal is as an academic text. It has several parts that have their respective functions. The initial part of the article is the introduction. As the first part written introduction has an important role, the introduction can lead readers from the general research problem to specific problem of research, readers can know about entire of research only by reading the introduction. Therefore, introduction is the first important part that needs to be carefully written anddeveloped during the writing of an academic writing, Wilkinson(1991:96), cited in Nora's research (2014) said that the introduction is the part that discovered all of the information of the research proposed and established a framework for the research so that the reader can understand about the research. Furthermore,Weissberg and Buker (1990: 20) stated that introduction is a direct part for readers that can give them the explanation that they need to understand information detailed about research Clearly, the introduction draws the research topic as a lead to help the readers to follow information of research of the statement of the problem, purpose and research questions, theoretical perspective, and limitation of the study.

As we know that the introduction in academic writing is very important, so experienced to write a good introduction must be trained, however, in writing introduction most researchers still faced difficulties, as Swales and Feak (2012: 327) claimed that some writers faced some obstacles in writing an introduction. They also found that many researchers have difficulties to start writing about the introduction, Nora, Yeni and Kurnia (2014) also found that this difficulty in writing introduction also faced by the students of English Education in STAIN Sketch. M. Djamil Djambek, Bukit Tinggi, the lecturers said that they 
often find some mistakes in the student's introduction writing, more than $70 \%$ of students' introduction unwell structured.

This obstacle also faced by the student's of UINSA, specifically students of English Education Department which English students have received written and research courses since the previous semester and of course have had the task of making various forms of academic writing such as articles, proposals, reports, papers and so on which have made many introduction writings, but in this course (Article academic writing) of 6th semester there are still many students who find difficulties in writing the introduction of research, this can be seen from them requiring a long time to write only the background part and need several times to do revisions, besides that it is not easy for them to highlight research topics orsignificant problems that important to be observed.

Moreover, writing and reading are often said to have a relationship. This can be seen from when someone will write, reading can have an important role in building ideas. After reading, the reader can free to develop their ideas about what they have read. They can rewrite the ideas that they get by reading before using their language. Though the ideas that they wrote were influenced by the reading that they had read, the formulation of writing was certainly still different, because they poured these ideas using their language. It is by Kessler (2006) cited in Farahzad and Emam (2010) stated that good writers are good readers and good reading is the key to becoming a good writer. Becoming a good writer works together with becoming a good reader. On the otherhand, Inayatul Maula (2015) on her research said that writing ability does not come from the actual writing experience, but from reading, beside it that Many research strongly suggest that write can start with reading first, for additional In additional, Pamuji (2013) stated that reading attitude can give positive effect for writing achievement.

There are some obstacles in writing the introduction of research, according to Swales and Feak (2012:328), or it can be from Rhetorical structure that way to organize the writing ideas, but, in the other hand, researcher interest to do a research betweenstudents reading habit and their introduction writing, because, as we know that reading is also important foreign language skills beside it reading habit is an essential aspect for creating literate society as it shapes the personality of an individual, helps to develop proper thinking methods, and create new ideas (Sadan, 2012).

Promoting reading habits is important, especially among the students, it for gaining their information it can get from the schoolbooks or other resources which can help students to understand or to solve the problems that they found in the learning materials, this is in line with Harry Madox said that reading is the most important single skill in study. But nowadays, the interest in reading books among students is diminishing, this is due to the more rapid and developing technology, therefore, in the study researchers will look in different ways, reading habit here is not just about reading about material from books, but will be seen from all types of reading that are read by the current generation.

Furthermore, the purpose of this studyare to find out the correlation between students' reading habit and their ability to write an introduction in Research Seminar Proposal,is there any significant correlation between students reading habit and their writing introduction achievement.

From the background above, there are some questions to identify the research problem:

1. Is there any correlation between a student's reading habit and writing skill introduction in the research seminar proposal?

2. How far the correlation between student's reading habits and writing skill introduction in research seminar proposal at the sixth of English Teacher Education Department of State Islamic University Sunan Ampel Surabaya?

The purposes of the study can be stated as follows:

1. To find out the correlation between student's reading habits and writing.

2. To measure the students' reading habit in the sixth semester of English Teacher Education Department at State Islamic University Sunan Ampel Surabaya.

After researching the influence of students' reading habit toward their writing skill in background research seminar proposal, the researchers hope that the result will be useful to give some contribution to English Language Teaching as follows:

1. For the teacher

We hope that the result of this research will be useful as the way to develop their strategy in teaching process about reading habit to increase the students' writing skill.

2. For the students

We hope that the finding of the research will be to motivate the students to develop their writing skills by reading habit.

3. For the other researchers

We hope that the finding of the research can be useful as the source of their reference.

\section{LITERATURE REVIEW}

1. Definition of Reading Habit

Reading is one of the most effective ways to be a good reader and good spelling, adequate vocabulary, sophisticated grammatical competence and developing a good writing style as well. Krashen (2004: 132) states that the writing style does not cause the actual writing experience but from reading. Many of the studies reviewed 
that those who read more, develop a higher level of literacy. Habit is a repetitive performance. Habit formation is a process where new behaviour becomes automatic, behaviour patterns. Reading habits refer to behaviour, which expresses the similarity between reading and reading taste (Sangkaeo, 1999: 1). This is how the reader arranges the reading and how often, how much, and what the reader reads.

Reading Habits is the set of behaviours relating to one's reading style as well as reading tastes and habits. The term is also included for the frequency of reading along with various topics and forms of written material (Newspapers, novels, religion, history, entertainment, etc.) Good reading habits are important for the development of personality and mental capacity. This habit is needed for healthy intellectual growth and plays an important role in enabling a person to achieve language skills (Grabe \& Stoller, 1997: 98). Reading gives readers great knowledge, by reading books frequently and having good reading habits, readers can analyze the ideas of others, which makes people think more critically. They need reading skills not only for learning something (lessons) but also for getting experience, knowledge, and everything which can support their future study in higher education. Therefore, it is obvious that reading is an important part of their life by Inayatul Maula (2015).

\section{Definition of Writing}

Writing is one of a crucial part of communication because through a writing students can transfer the information and knowledge they have to others. Besides, writing is also a way to express the ideas. According to Elshtain as quoted by Murcia, a text can be said as a communication action. Through a text can also occur interaction between readers and writers. (Boston: Thomson Learning Inc,2001). It means that both the writer and the reader play an importantrole in written communication, while writing may become a challenging skill for students. It is also considered as the most complicated activities compared to three other language skills in English. As Brown stated that writing is a complex activity that requires a great deal of expertise to translate ideas into a piece of paper. Besides, to compose a good writing requires some coordination such as vocabulary, grammar, critical thinking skills, background knowledge, etc.

\section{Style to write the introduction}

The rhetorical structure is a way to "frame" or to "organize" the writing to communicate ideas which function is to shape the progression of the idea (Hult, 1987:19). It is supported by Swales (1990:138) who argues that the researchers need rhetorical structure to address and to arrange their goals, current capacities, problems and criteria of evaluation in writing introduction, he proposed a rhetorical structure or movement as a model to write an introduction; that is Create A Research Space (CARS) model (Swales, 1990: 140, Swales and Feak, 2102: 331).
This rhetorical movement consists of three move steps structure. They are Establishing the Territory (Move 1), Establishing a Niche (Move 2) and Occupying a Niche (Move 3).

\section{Introduction}

The introduction section is the firstpart written in a research proposal.As the first part is written, theintroduction serves an important rolefor it sets the stage for the entirestudy. Besides, it draws theresearcher's ideas and interest in theproblems. Hence, the introductionsection would likely be the first partthat needs to be carefully written anddeveloped during the writing of aresearch proposal.Wilkinson (1991:96) said that the introduction is the part thatprovides the readers with thebackground information of theresearch proposed and establishes aframework for the research so thatthe reader can understand how it isrelated to other research.

Besides, Weissberg and Buker (1990: 20) saythat the introduction part serves as anorientation for the readers and givesthem the perspective they need tounderstand the detailed informationcoming in the later sections.The introduction draws the researchtopic as a lead-in to help the readersto follow the logic of the proposal for it states the statement of the problem, purpose and research questions, theoretical perspective, and limitation of the study.

\section{METHODOLOGY}

\section{A. Research design}

The researcher will use a quantitative design. Quantitative research is an investigation of social problems that explains about phenomena by collecting numerical data which is analyzed using a mathematical method. (Aliaga and Gunderson, 2002). According to Creswell (2003), when quantitative research is chosen, the researcher uses the post positivitis approach to develop knowledge.

\section{B. Participants}

The participants of this research are the students of the English Teacher Education Department at the State Islamic University of Sunan Ampel Surabaya. The sample is 33 students of Research Seminar Proposal A class for becoming the participant of this research.

\section{Data collection}

In this process, the researcher will use questionnaires to collect the data, questionnaires will give online to the students and the researcher asks students to fill all of the questionnaires from the researcher, this questionnaire will share with the group WhatsApp of students A class in Research Seminar Proposal.

\section{Data analysis}

After getting the data, the researcher categorizes the responses based on the research. Then, the researcher analyzes the data from the participants and the researcher 
use SPSS to find the data of the research question in this research.

\section{FINDINGS AND DISCUSSION}

A. Research Finding

For the first result in this study, the researcher does normality and Linear Regression tests.

B. The Test of Normality

a. A normality test is done to determine the normal distribution of data. The researcher uses Kolmogorov Smirnov to test the normality. The criteria of test normality significant are: A normal distribution of data if the value of significance $>0,05$

b. A not normal distribution of data if the value of significance $<0,05$

The data in this research is analyzed by SPSS version 16 . The result of the normality test can be seen in the following table:

\begin{tabular}{|ll|l|}
\hline & & $\begin{array}{l}\text { Unstandardized } \\
\text { Residual }\end{array}$ \\
\hline $\mathrm{N}$ & Mean & 30 \\
Normal & .0000000 \\
Parameters & Std. Deviation & 2.47624417 \\
Most & Extreme Absolute & .173 \\
Differences & Positive & .086 \\
& Negative & -.173 \\
Kolmogorov-Smirnov Z & .949 \\
Asymp. Sig. (20tailed) & .329 \\
\hline
\end{tabular}

a. Test distribution is Normal.

Based on the value of normality test above, it shows that significant $0,329(>0.05)$. So we can take the conclusion that test distribution is Normal.

\section{Linear Regression Test}

a. In this part, the researcher will compare the significant value with probabilities 0.05 .

b. If the significant $<0,05$ it means that Variable $\mathrm{X}$ influence Variable $\mathrm{Y}$

c. If the significant $>0.05$ it means that Variable $\mathrm{X}$ did not influence Variable Y

d. Compare tamount with table

e. If amount $>$ table it means that Variable $\mathrm{X}$ influence Variable $\mathrm{Y}$

f. If amount $<$ table it means that Variable $X$ did not Influence Variable $\mathrm{Y}$

\section{Model Summary}

\begin{tabular}{|l|l|l|l|l|}
\hline Model & R & R Square & $\begin{array}{l}\text { Adjusted R } \\
\text { Square }\end{array}$ & $\begin{array}{l}\text { Std. An error } \\
\text { oftimate }\end{array}$ \\
\hline 1 & .888 & .788 & .781 & 2.52007 \\
\hline
\end{tabular}

b. Predictors: (Constant), READING HABIT)

From the table above it shows that the correlation $\mathrm{R}$

is 0.88. From the output above getting coefficient determination ( $\mathrm{R}$ Square) 0.788. It means that influence Variable X (Reading Habit) with Variable Y (Writing background in a seminar research proposal) is $78.8 \%$. It can be concluded that there is a positive correlation between $\mathrm{X}$ and $\mathrm{Y}$.

\section{Coefficients $^{\mathbf{a}}$}

\begin{tabular}{|c|c|c|c|c|c|}
\hline \multirow[t]{2}{*}{ Model } & \multicolumn{2}{|c|}{$\begin{array}{l}\text { Unstandardized } \\
\text { Coefficients }\end{array}$} & $\begin{array}{l}\text { Standardized } \\
\text { Coefficients }\end{array}$ & \multirow{2}{*}{$\mathrm{t}$} & \multirow{2}{*}{ Sig. } \\
\hline & B & $\begin{array}{l}\text { Std. } \\
\text { Error }\end{array}$ & Beta & & \\
\hline $\begin{array}{l}1 \text { (Constant) } \\
\text { READING } \\
\text { HABIT }\end{array}$ & $\begin{array}{l}45.402 \\
.638\end{array}$ & $\begin{array}{l}3.297 \\
.062\end{array}$ & .888 & $\begin{array}{l}13.771 \\
10.210\end{array}$ & $\begin{array}{l}.000 \\
.000\end{array}$ \\
\hline
\end{tabular}

\section{c. Dependent Variable: WRITING SKILL}

Based on the table shows, the significant coefficient is $0.000<0.05$. It can be concluded that there is a correlation between reading habits and writing background research seminar proposals. Because Variable X influence Variable Y. Besides, based on the value of $t$. It can be

showed tamount $10.210>\mathrm{T}_{\text {table }} 2.048$. It means that variable $\mathrm{X}$ influence Variable $\mathrm{Y}$, then there is a positive correlation between $\mathrm{X}$ and $\mathrm{Y}$.

The finding of this study shows that the participants in this study have the same appointment. Students that have reading habit provided a great effect in their background writing skill. It shows that reading gives a big effect on their academic writing skill. Besides, that reading was very important for them. It built up inspiration/ ideas, promoted critical analysis, enhanced knowledge, enrich. Based on this finding, this research shows that the mean scores between reading habit and writing background, there is a correlation. The students who have a good reading habit also have a good skill writing ability. It means that reading habit gives effect on a students' in writing background. It was proved by the computation using a one- 
sample Kolmogorov-Smirnov test which shown that the significant positive $0,329(>0.05)$ and also a significant coefficient is $0.000<0.05$. Hence, based on hypothesis testing, the null hypothesis was rejected. Thus, the finding means that reading habit gives a significant effect on students' ability in writing background research seminar proposal.

Reading activity is effective in building up students' ability in writing background research seminar

proposal. By a lot of reading, the students' will have many ideas and knowledge to start and develop their writing. Reading plays an important role in building ideas. Readers are free to develop their interpretations of what they read by writing it into a written text. Inspite of the their writing have been influenced by their reading, the formation of writing texts is still different. Students reading habits is to influence their writing skills. The students who have a good reading habit they also have good skill in writing skill.

This statement has known in the academic environment. This study provided some finding of reading habits and its effects on academic writing skills. Reading had a big effect on academic writing skills. The quality of writing product showed how many times the writer read. In academic writing, reading references encouraged the writer to be acritical thinker so that the quality of writing products would be more acceptable. Moreover, If it became a lifelong reading, it would make students more creative and productive (Gardiner, 2005: 128).

\section{CONCLUSION}

In this study, the researcher concludes that there is a correlation between students' reading Habit of Seminar Proposal course and their writing background skill. This phenomenon was caused by several reasons such as; 1) most of the students spent their time to get information by reading, 2) students were interested in reading academic and nonacademic books, 3) more students involved in reading and writing activity. Reading is an activity that can involve writing ability, vocabulary, spelling, and grammar. The repetition and intentional activity of reading are called reading habits, but nowadays, students have less attention to read a book since the development of media technology and bring them to pay less attention to read.

Reading plays an important role in writing. Writing is the way for expressing ideas considering the right words and right sentences and making related to the thinking development. Learners are now facing the writing problem such as lack of writing material and minor knowledge toward target language. Moreover, reading and writing are connecting. Reading also influences writing ability since the parts of reading acquirement take a role in writing production. The purpose of this study was to find out the students' reading habits whether there was an effect on writing skills in developing their ideas when writing. The researcher has administered a questionnaire and writing test to obtain the data to all groups.

From the questionnaire, there were 33 students, almost all of them who have good reading habits. And also admit to read often and prefer to read fiction and non-fiction books. They acknowledge that reading influences them in academic performance, especially in writing. It is proven by the research finding that shows the effect of significant among reading habits and writing background. Moreover, the Analysis of the one-sample Kolmogorov-Smirnov test showed that there is an effect among those reading habits and writing.

\section{REFERENCES}

[1] Arif Pamuji.2015.The Correlation Between Reading Achievement and Writing Achievement to the Eight Graders of Bilingual Class At SMP Negeri 1 Palembang.

Gardiner, Steve. Building Student Literacy Through Sustained Silent

Reading. USA: Association for Supervision and Curriculum Develop

[2] Hyland.2015. The correlation between students' reading habits and their ability to write narrative text. Semarang.

[3] Inayaul Maula. 2018. The correlation between student's critical thinking ability, Reading, and Listening Comprehension. Surabaya.digilib.uinsby.ac.id

[4] Mahyar, U. (2012). The Influence of Reading Habit on Students Writing Skills. Sekolah Tinggi Keguruandan Ilmu Pendidikan (STKIP) Siliwangi Bandung.

[5] Palani, K. K. (2012) Promising Reading Habits and Creating Literate Social. International Reference Research Journal Vol. III Issue 2(1) pp 91. Smith, F. 1994. Writing and the Writer (2nd Ed). Hillsdale, NJ:Erlbaum. 